\title{
Transurethral Resection of Ejaculatory Duct in Primary Infertile Men with Distal Ejaculatory Duct Obstruction
}

\section{Distal Ejakülatuvar Kanal Tıkanıkı̆ğ Olan Primer Infertil Erkeklerde Transüretral Ejakülatuvar Kanal Rezeksiyonu}

\author{
(1) Cevahir Özer, (1) Mehmet Reşit Gören \\ Başkent University Faculty of Medicine, Department of Urology, Adana, Turkiye
}

\section{What's known on the subject? and What does the study add?}

Distal ejaculatory duct obstruction is a rare but treatable cause of male infertility. The standard treatment of distal ejaculatory duct obstruction is transurethral resection of ejaculatory duct. The improvement of sperm parameters by transurethral resection may decrease the need for assisted reproduction methods and allow the use of ejaculated sperm.

\begin{abstract}
Objective: We evaluated the outcome of transurethral resection for the treatment of distal ejaculatory duct obstruction with primary infertile men. Materials and Methods: We retrospectively evaluated 23 primary infertile men, who had distal ejaculatory duct obstruction, between June 2006 and July 2018. All patients were treated by transurethral resection of the ejaculatory duct.

Results: The mean age of the patients was $31.82 \pm 5.01$ years. Preoperative and postoperative seminal parameters were compared. There was a statistically significant increase in ejaculate volume, sperm concentration, sperm motility and total motile sperm count.

Conclusion: Transurethral resection of the ejaculatory duct improved sperm parameters in most of the primary infertile men with distal ejaculatory duct obstruction. Transurethral resection may also decrease the need for assisted reproduction methods and allow in-vitro fertilization/ intracytoplasmic sperm injection with ejaculated sperm in some azoospermic patients.
\end{abstract}

Keywords: Ejaculatory duct obstruction, Transurethral resection, Male infertility

$\ddot{0 z z}$

Amaç: Distal ejakülatuvar kanal tıkanıklığı olan primer enfertil erkeklerin tedavisinde transüretral rezeksiyonun sonucunu değerlendirdik.

Gereç ve Yöntem: Haziran 2006 ile Temmuz 2018 arasında distal ejakülatör kanal tıkanıklığı tanısı alan 23 primer enfertil erkeği retrospektif olarak değerlendirdik. Tüm hastalar ejakülatör kanalın transüretral rezeksiyonu ile tedavi edildi.

Bulgular: Hastaların yaş ortalaması 31,82 $\pm 5,01$ yıldı. Hastaların ameliyat öncesi ve sonrası seminal parametreleri karşılaştırıldı. Ejakülat hacminde sperm konsantrasyonunda, sperm hareketinde ve total motil sperm sayısında istatistiksel olarak anlamlı bir artış vardı.

Sonuç: Ejakülatör kanalın transüretral rezeksiyonu distal ejakülatuvar kanal tıkanıklığı olan primer enfertil erkeklerin çoğunda sperm parametrelerinde iyileşme sağlar. Ayrıca, transüretral rezeksiyon yardımla üreme yöntemleri ihtiyacını azaltabilir ve başlangıçta azoospermik olan hastalarda ejakülat spermi kullanılarak in vitro fertilizasyon/intrasitoplazmik sperm injeksiyonu yapılmasına olanak sağlayabilir.

Anahtar Kelimeler: Ejakülatuvar kanal kisti, Transüretral rezeksiyon, Erkek infertilitesi

Correspondence: Cevahir Özer, Başkent University Faculty of Medicine, Department of Urology, Adana, Turkiye Phone: +90 3223272727 E-mail: cevahirozer@gmail.com ORCID-ID: orcid.org/0000-0001-6037-7991

Received: 01.12.2018 Accepted: 02.01.2019

Cite this article as: Özer C, Gören MR. Transurethral Resection of Ejaculatory Duct in Primary Infertile Men with Distal Ejaculatory Duct Obstruction. J Urol Surg 2019;6(2):135-138.

๑Copyright 2019 by the Association of Urological Surgery / Journal of Urological Surgery published by Galenos Publishing House. 


\section{Introduction}

Distal ejaculatory duct obstruction (EDO) affects 1-5\% of infertile men (1). It can be classified as complete or partial and can be congenital or acquired (2). Congenital causes may be in the form of atresia or stenosis of ejaculatory duct and cystic lesions such as Mullerian duct (utricular) or Wolffian duct (diverticular) cysts (3). Acquired causes may be secondary to infectious or inflammatory etiologies or trauma, either iatrogenic or otherwise (4).

Patients with EDO may have various complaints such as low ejaculate volume, non-projectile ejaculation, pain during or after ejaculation, hematospermia, dysuria or infertility $(2,5)$. Typically, semen analysis shows low-volume azoospermia or oligozoospermia (3).

Although vasography is accepted as the gold standard for diagnosis, transrectal ultrasound (TRUS) has become the essential imaging modality because of its less invasive nature (6). The standard treatment procedure for distal EDO is transurethral resection of the ejaculatory ducts (TURED) (7). Several studies in which patients treated with TURED for infertility showed improvement of semen parameters in $37.5-100 \%$ of cases $(4,8,9,10)$.

In this study, we aimed to discuss the TURED results in our primary infertile patients with distal EDO and compare them with the previous literature.

\section{Materials and Methods}

A total of 23 patients with primary infertility, who had undergone TURED for distal EDO between June 2006 and July 2018, were evaluated. All data were obtained in accordance with the privacy protection policy of our institution. The patients were evaluated by using a detailed history, physical examination and hormonal analysis (follicle-stimulating hormone, luteinizing hormone and total testosterone). Six patients with missing data were excluded and the remaining 17 patients were included in the study. Informed consent was obtained from all patients before the operations. The study protocol was approved by our institutional review board.

Semen analysis was carried out at least twice for each patient. Semen samples were collected and evaluated in accordance with the World Health Organization standards (11). Retrograde ejaculation was ruled out by postejaculation urine analysis. TRUS and/or magnetic resonance imaging (MRI) were performed to evaluate prostate and seminal vesicles.

All operations were done under sedoanalgesia with the patient in the lithotomy position. Transurethral resection was performed as described by Farley and Barnes (12). In 5 patients, the procedure was performed with methylene blue injected into the seminal glands under TRUS guidance. Electrocauterization for hemostasis was used carefully to avoid iatrogenic obstruction. A Foley catheter was placed at the end of the operation and removed on postoperative first day. All patients received intravenous perioperative antibiotic prophylaxis with cefazolin. No perioperative complications were observed.

Semen analysis was performed after at least 6 weeks of TURED.

\section{Statistical Analysis}

Improvement was defined as $>50 \%$ increase in sperm parameters including ejaculate volume, sperm concentration and sperm motility after TURED. For each continuous variable, normality was checked by the Kolmogorov-Smirnov test, Shapiro-Wilk test and histograms. The variables between the groups were analyzed using the Wilcoxon test. The data were analyzed using the Statistical Package of Social Science (Version 24.0; SPSS Inc., Chicago, IL, USA). A p value o less than 0.05 was considered statistically significant.

\section{Results}

The mean age of the patients was $31.82 \pm 5.01$ years. Testicular volume was normal, and the vas deferens was bilaterally palpable in all men. There were no pathological findings on the rectal examination. Serum hormone levels were within the normal ranges in all patients.

Fourteen patients (82.4\%) had complete and $3(17.6 \%)$ had incomplete obstruction. According to the underlying cause, 11 patients had cystic lesions and 6 patients had non-cystic stenosis (Table 1).

The mean duration of postoperative follow-up period was 16.29 \pm 14.26 months (range, 3-46 months). Mean ejaculate volume, sperm concentration and motility before and after surgery in men with partial and complete EDO are shown in Table 2. Preoperative and postoperative seminal parameters of patients were compared. There was a statistically significant increase in ejaculate volume, sperm concentration, sperm motility and TMSC.

Intracytoplasmic sperm injection (ICSI) procedure was recommended for 6 patients with complete obstruction who had sperm in ejaculate after TURED. Four patients accepted the procedure; ICSI was performed with ejaculated sperm. Testicular sperm retrieval was recommended for 8 patients with complete obstruction who were still azoospermic after TURED. In 5 of these patients, who accepted the testicular sperm retrieval, ICSI procedure was performed with testicular sperm. In a patient from the partial EDO group, pregnancy was achieved with intrauterine insemination (IUI). Waiting for spontaneous 
pregnancy was recommended for 1 couple. In the remaining patient, ICSI was performed with ejaculated sperm.

Azoospermia developed in 1 patient in the late postoperative period.

\section{Discussion}

Distal EDO is rare but is one of the surgically correctable causes of male infertility $(3,7)$. Distal EDO occurs in 2 forms, complete (classic) and partial. In complete form, complete blockage of the ejaculatory ducts is present. Patients with complete form have low-volume azoospermia. In partial form, there is unilateral complete or bilateral partial physical obstruction of ejaculatory ducts. Partial EDO is typically associated with low to normal volume oligoasthenospermia (10).

Historically, vasography was the gold standard for diagnosing EDO (4). However, besides radiation exposure, this invasive method has some iatrogenic risks such as stricture and vasal occlusion $(4,6)$. Therefore, TRUS is considered the initial radiological imaging method for evaluating cases with suspicion of distal $\operatorname{EDO}(2,6)$. The TRUS criteria put forward for distal EDO are dilated seminal vesicles with a width $>1.5 \mathrm{~cm}$, dilated ejaculatory ducts, calcification or calculi inside the ejaculatory ducts or verumontanum and Müllerian or Wolffian duct cysts near the verumontanum (6). MRI provides a good image of equal quality. However, both imaging modalities are not sufficient to observe the status of the ejaculatory ducts (6).

TURED is regarded the standard treatment for distal EDO (5).

Table 1. Outcomes of subgroups of transurethral resection of ejaculatory duct

\begin{tabular}{llll}
\hline & $\begin{array}{l}\text { Complete } \\
\text { EDO (n) }\end{array}$ & $\begin{array}{l}\text { Partial } \\
\text { EDO (n) }\end{array}$ & $\begin{array}{l}\text { Total } \\
\text { (n) }\end{array}$ \\
\hline $\begin{array}{l}\text { Patients with cystic lesion } \\
\text { Improvement in only ejaculate }\end{array}$ & 3 & - & 3 \\
$\begin{array}{l}\text { volume } \\
\text { Improvement in only concentration }\end{array}$ & 2 & - & 2 \\
Improvement in only motility & - & - & - \\
Improvement in concentration and & - & 1 & 1 \\
TMSC & 1 & 1 & 2 \\
Improvement in all parameters & 3 & - & 3 \\
No improvement & & & \\
\hline Patients with non-cystic obstruction & & & \\
Improvement in only ejaculate & 2 & - & 2 \\
volume & & & - \\
Improvement in only concentration & - & - & - \\
Improvement in only motility & - & - & 4 \\
Improvement in all parameters & 3 & 1 & 17 \\
\hline Total & 14 & 3 & \\
\hline
\end{tabular}

EDO: Ejaculatory duct obstruction, TMSC: Total motile sperm count
When resection is performed at the correct level, the flow of cloudy, milky fluid from the opened ducts is usually seen $(6,13)$. Instillation of methylene blue or indigo carmin into seminal vesicles may help identify the ejaculatory ducts during resection (13). Semen analysis can be carried out as early as 2 weeks after TURED procedure (6).

Previously published data in a group of infertile males with distal EDO have shown that the improvement of semen parameters was $37.5-100 \%(4,8,9,10)$. In our study, $82 \%$ of patients showed improvement in at least one sperm parameter. El-Assmy et al. (10) reported that the improvement of the sperm parameters in 17 patients with complete form was $23.5 \%$. Yurdakul et al. (8) reported that spermatozoa were observed in the ejaculate of 11 patients following TURED in their retrospective study of 12 patients with complete form. In our study, after TURED, spermatozoa were seen in the ejaculate of 6 patients with complete form (42.8\%). When evaluated statistically, we found a significant increase in ejaculate volume, sperm concentration, sperm motility and TMSC.

The underlying problem is not clear in patients who do not improve despite surgical treatment. This problem is thought to be associated with seminal vesicle dysfunction causing inadequate transfer of the sperm or epididymal obstruction (14).

El-Assmy et al. (10) reported that the type of distal EDO (complete and partial) and etiology of obstruction (cystic lesion and noncystic lesion) were predictive factors for operative success. The outcome was better in patients with partial form and with cystic complete form (10). In our study, the success was higher in the partial and non-cystic complete cases. However, the number of patients is insufficient for statistical interpretation.

Patients with distal EDO, especially those with complete form, are candidates for in-vitro fertilization (IVF)/ICSI. TURED allows us to offer other options such as waiting for spontaneous pregnancy and IUI to some of these patients. In addition, TURED can spare a group of complete form patients from a testicular sperm retrieval procedure for ICSI (15). In our study, 6 of the complete form patients had an ICSI procedure with ejaculated sperm.

TURED has some potential complications such as

Table 2. Preoperative and postoperative seminal parameters

\begin{tabular}{llll}
\hline Parameter & $\begin{array}{l}\text { Before surgery } \\
(\text { mean } \pm \text { SD) }\end{array}$ & $\begin{array}{l}\text { After surgery } \\
(\text { mean } \pm \text { SD) }\end{array}$ & $\mathbf{p}$ \\
\hline Ejaculate volume $(\mathrm{mL})$ & $0.43 \pm 0.36$ & $1.87 \pm 1.76$ & 0.001 \\
\hline $\begin{array}{l}\text { Sperm concentration } \\
\left(\mathrm{x} 10^{6} / \mathrm{mL}\right)\end{array}$ & $4.49 \pm 6.94$ & $16.62 \pm 35.93$ & 0.012 \\
\hline Sperm motility $(\%)$ & $5.00 \pm 20.61$ & $18.35 \pm 28.30$ & 0.028 \\
\hline TMSC & $2.45 \pm 10.10$ & $21.79 \pm 51.85$ & 0.018 \\
\hline
\end{tabular}

SD: Standard Derivation, TMSC: Total motile sperm count 
epididymoorchitis, hematuria, urinary incontinence due to external sphincter damage, retrograde ejaculation due to bladder neck damage, urethral stricture and rectal injury $(4,6,10)$. Patients should also be informed about such adverse outcomes. Azoospermia has been reported in about $4 \%$ of patients with partial EDO treated with $\operatorname{TURED}(13,16)$. In the late postoperative period, azoospermia developed in 1 of our patients who improved from complete EDO to normal volume oligoasthenospermia. The development of azoospermia may be secondary to postoperative fibrosis of the ejaculatory ducts $(10,16)$.

\section{Study Limitations}

One of the limitations of this study is its retrospective nature. Furthermore, the sample size was small and the sub-parameters were not available for analysis.

\section{Conclusion}

TURED significantly improves sperm parameters in most of primary infertile men with distal EDO. TURED may also decrease the need for assisted reproduction methods such as IVF/ICSI and allow IVF/ICSI with ejaculated sperm in some patients with complete obstruction at baseline.

\section{Acknowledgments}

The authors would like to thank Çağla Sarıtürk, Başkent University Adana Dr. Turgut Noyan Medical and Research Center, Biostatistics Unit.

\section{Ethics}

Ethics Committee Approval: This study was approved by Baskent University Institutional Review Board (approval number: KA18/277).

Informed Consent: Because of its retrospective nature, no written informed consent was obtained from the patients.

Peer-review: Externally peer-reviewed.

\section{Authors Contrubitions}

Concept: C.Ö., M.R.G., Design: C.Ö., M.R.G., Data Collection and/ or Processing: C.Ö., Analysis and/or Interpretation: C.Ö., M.R.G., Literature Research: C.Ö., M.R.G., Writing: C.Ö., M.R.G.
Conflict of Interest: No conflict of interest was declared by the authors.

Financial Disclosure: The authors report no competing personal or financial interests.

\section{References}

1. Pryor JP, Hendry WF. Ejaculatory duct obstruction in subfertile males: analysis of 87 patients. Fertil Steril 1991;56:725-730.

2. McQuaid JW, Tanrikut C. Ejaculatory duct obstruction: current diagnosis and treatment. Curr Urol Rep 2013;14:291-297.

3. Pace G, Galatioto GP, Guala L, Ranieri G, Vicentini C. Ejaculatory duct obstruction caused by a right giant seminal vesicle with an ipsilateral upper urinary tract agenesia: an embryologic malformation. Fertil Steril 2008;89:390-394.

4. Fisch $H$, Lambert SM, Goluboff ET. Management of ejaculatory duct obstruction: etiology, diagnosis, and treatment. World J Urol 2006;24:604610.

5. Fisch $\mathrm{H}$, Kang $\mathrm{YM}$, Johnson CW, Goluboff ET. Ejaculatory duct obstruction. Curr Opin Urol 2002;12:509-515.

6. Modgil V, Rai S, Ralph DJ, Muneer A. An update on the diagnosis and management of ejaculatory duct obstruction. Nat Rev Urol 2016;13:13-20.

7. Paick J, Kim SH, Kim SW. Ejaculatory duct obstruction in infertile men. BJU Int 2000;85:720-724.

8. Yurdakul T, Gokce G, Kilic O, Piskin MM. Transurethral resection of ejaculatory ducts in the treatment of complete ejaculatory duct obstruction. Int Urol Nephrol 2008;40:369-372.

9. Netto NR, Jr., Esteves SC, Neves PA. Transurethral resection of partially obstructed ejaculatory ducts: seminal parameters and pregnancy outcomes according to the etiology of obstruction. J Urol 1998;159:2048-2053.

10. El-Assmy A, El-Tholoth H, Abouelkheir RT, Abou-El-Ghar ME. Transurethral resection of ejaculatory duct in infertile men: outcome and predictors of success. Int Urol Nephrol 2012;44:1623-1630.

11. WHO W. WHO laboratory manual for the examination and processing of human semen. World Health Organization, Geneva 2010.

12. Farley S, Barnes R. Stenosis of ejaculatory ducts treated by endoscopic resection. J Urol 1973;109:664-666.

13. Smith JF, Walsh TJ, Turek PJ. Ejaculatory duct obstruction. Urol Clin North Am 2008;35:221-227, viii.

14. Ozgok Y, Tan MO, Kilciler M, Tahmaz L, Kibar Y. Diagnosis and treatment of ejaculatory duct obstruction in male infertility. Eur Urol 2001;39:24-29.

15. Kadioglu A, Cayan S, Tefekli A, Orhan I, Engin G, Turek PJ. Does response to treatment of ejaculatory duct obstruction in infertile men vary with pathology? Fertil Steril 2001;76:138-142.

16. Turek PJ, Magana JO, Lipshultz LI. Semen parameters before and after transurethral surgery for ejaculatory duct obstruction. J Urol 1996:155:1291-1293. 